Article

\title{
Circuit Training during Physical Education Classes to Prepare Cadets for Military Academies Tests: Analysis of an Educational Project
}

\author{
Pietro Luigi Invernizzi ${ }^{1}$, Gabriele Signorini ${ }^{1}$, Maurizio Pizzoli ${ }^{2}$, Giampietro Alberti ${ }^{1}$, \\ Damiano Formenti ${ }^{3, *}{ }^{1}$ and Andrea Bosio ${ }^{4}$ \\ 1 The Department of Biomedical Sciences for Health, University of Milan, 20129 Milan, Italy; \\ pietro.invernizzi1@unimi.it (P.L.I.); gabriele.signorini@unimi.it (G.S.); giampietro.alberti@unimi.it (G.A.) \\ 2 Teulié Military School, 20122 Milan, Italy; m.pizzoli@tiscali.it \\ 3 The Department of Biotechnology and Life Sciences (DBSV), University of Insubria, 21100 Varese, Italy \\ 4 Human Performance Laboratory, Mapei Sport, 21057 Varese, Italy; andrea.bosio@mapeisport.it \\ * Correspondence: damiano.formenti@uninsubria.it
}

Received: 4 June 2020; Accepted: 19 June 2020; Published: 23 June 2020

\begin{abstract}
Background: The aim of this study was to test the efficacy of an eight-week physical education program based on circuit training to better improve the overall physical and military-specific performance compared to a conventional physical education program in military high school students. Methods: Sixty-four students were enrolled in this study and randomly assigned to an experimental (EG, circuit training) or a control group (CG, traditional physical education program). Immediately before and after the eight-week training period, participants were tested on strength and endurance performance, circuit training tests, and military tests. Moreover, the acquisition of the educational objectives and the pleasantness of the experimental intervention were tested using a qualitative approach. Results: Despite the higher workload in EG than CG during the training period, the effect of the experimental intervention compared to the control was only possibly to likely positive for a few strength and endurance performances and circuit training tests, respectively. A trivial effect was shown in the military tests. On the contrary, the high percentage of motivation (76\%), understanding $(78 \%)$ and collaboration $(86 \%)$ showed by the students suggests the achievement of acquisition of the educational objectives and a fair pleasantness of the lessons. Conclusions: A lack of clear and marked effect of the experimental intervention could be ascribed to an insufficient exposure time to the training and a high subjective overall workload encountered in military high school students.
\end{abstract}

Keywords: high school; research-action; program for competences; quantitative and qualitative research

\section{Introduction}

Physical fitness represents one of the most important aspects for military personnel [1] and good levels of endurance, force and power are pivotal for individuals who choose this profession [2]. Furthermore, some specific physical complex competences such as dragging and transporting a wounded person are also necessary and are part of the training of soldiers [3]. Indeed, in some countries all over the world, being successful in certain specific cultural, psychological and physical tests is compulsory to enter army careers at different levels (soldier, non-commissioned officer, officer) [4]. The army career can begin at a young age by attending military schools from the age of 16. These schools have the main aim of preparing young persons for military academies and the attitudinal tests to access them. Besides, as schools, the educational aspects should be observed and, concerning physical education, physical literacy should be included. Physical literacy can be defined 
as a set of physical competences, motivation, confidence, knowledge and understanding necessary for physical activity during the lifespan considering individual characteristics [5]. An emergent concept in the present interpretation of physical literacy is competence with the meaning of proven capacity of facing an individual task or groups of tasks (e.g., study, work, personal development), using a structured set of knowledge (procedural or declaratory), abilities (cognitive, physical) and attitudes (personal, social, interpersonal) [6,7]. Indeed, these observations highlight that students have to learn how to manage the knowledge and abilities acquired. Given these premises, pedagogy should focus on teaching and learning methods that stimulate reflection and consciousness through a constant process of metacognition [8]. In this context, a research style where the researcher works explicitly with and for students, rather than only for research results [9], can be appropriate. The reality task of reflection-action used in the present project is composed of academy entrance physical tasks that represent a complex and problematic situation to fix using the abilities acquired during the student's experience and transferring them into a different context compared to didactic daily practice [10].

\subsection{The Operative Context}

The Teulié Military High School is an Italian military high school where cadets study to graduate and get prepared for the military academies. Programs and teaching are the same as in conventional schools and physical education lessons do not encompass any specific training typical of soldiers. This might not be sufficient to train and prepare cadets for the physical tests that are mandatory to access the academies. Adding specific training for this aim is not always feasible due to the large daily psychophysical load already undertaken by the cadets. For these reasons, part of the physical education lessons should be implemented with specific activities and the so-called "circuit training" [1] might represent a valid tool. In this context, the purpose of the present research evidences how physical education, in order to acquire social usefulness even in the last years of a high school, has to build connections that can be useful for the objectives of physical and specific disciplines. This could represent the way to promote useful experiences for a multicultural vision where the notions acquired in other disciplines can be really applied to the gym environment [8].

Moreover, physical education should aspire to complete individual formation, to the construction of the self, to the building of right and significant relationships with others and positive interactions with social and scientific realities $[9,10]$. In a rapidly changing society that requires critical and reflexive thinking, communication and collaboration capacities, psychophysical energy, self-management in uncertainty and a capacity for self-control, physical education is crucial for building citizenship competence and soft skills for a better quality of life $[8,10]$.

\subsection{Aim of The Study}

The main aim of the present study was to verify whether a specific training, which alternates sessions of circuit training and sessions of power training for lower and upper limbs, could enhance overall physical performance compared to a conventional physical education program based on sport activity in a classical and scientific military high school. The second aim was to investigate whether this kind of training can determine an improvement in the results of the physical entrance tests for the military academies. We hypothesized that this specific situation involving students into reality tasks can stimulate them through a reflexive approach and the use of cognitive, affective, and relational resources to reach a goal. A quantitative and a qualitative approach was used to verify this construct. Of note, this study intends also to fill a gap in the literature considering the lack of data regarding the physical fitness of students of military high schools. 


\section{Materials and Methods}

\subsection{Participants}

Seventy students of the Teulié Military School of Milano volunteered to participate in this study. The students regularly participated in two physical education lessons per week of $1 \mathrm{~h}$ each. Of these seventy students, only sixty-four completed the experimental training period and were included in the analysis. All participants were eighteen years old and were randomly divided into an experimental group $(n=27,10$ females and 17 males; body mass $=67.9 \pm 9.8 \mathrm{~kg}$; height $=1.72 \pm 0.1 \mathrm{~m}$; body mass index $\left.=23 \pm 2.3 \mathrm{~kg} \cdot \mathrm{m}^{-2}\right)$ and a control group $(\mathrm{n}=36,15$ females and 21 males; body mass $=67.0 \pm 6 \mathrm{~kg}$; stature $=1.72 \pm 0.1 \mathrm{~m}$; body mass index $\left.=22.7 \pm 1.5 \mathrm{~kg} \cdot \mathrm{m}^{-2}\right)$. All participants were informed about the purpose and the experimental protocol of the study. They provided written informed consent before the investigation. In accordance with the Declaration of Helsinki, the study was approved by the Ethics Committee of the University of Milano (approval number: 2/12). Moreover, this study was approved by the Teulié Military School.

\subsection{Functional-Quantitative Approach, Product Referred}

\subsubsection{Experimental Protocol}

The present study was carried out using a pretest-posttest, randomized, controlled design. A testing session was scheduled one week before the start of the training period, including the bench press test (BPT) [11] to assess strength and power of the upper limbs, the countermovement jump test (CMJ) [12] to assess strength and power of the lower limbs, and the Yo-Yo Intermittent Recovery Level 1 Test (Yo-Yo IRL1) [13] to assess cardio-respiratory fitness. Furthermore, the ability to execute the maximal number of repetitions within $1 \mathrm{~min}$ in different exercises of a circuit training (CTT) session, and military-specific skills tests (Military Test, MT) were also assessed. Participants underwent a preliminary session before the pre-test session to familiarize themselves with all the testing procedures. The experimental design is shown in Figure 1.

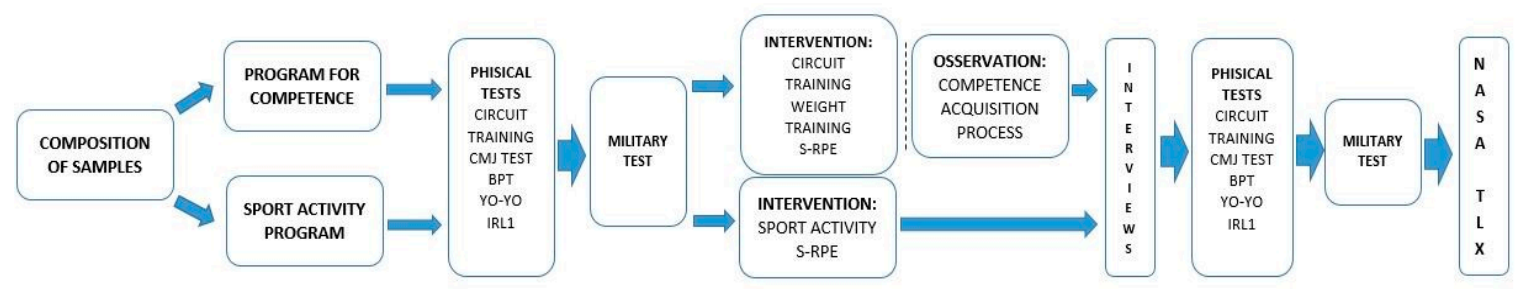

Figure 1. Experimental design.

\subsubsection{BPT}

The BPT is a test to assess the explosive force of the upper limbs [11]. Participants performed 3 repetitions at maximal speed with a starting weight of $20 \mathrm{~kg}$ (10 kg for women) and after 2 min of rest, a further load of $10 \mathrm{~kg}$ was added to the barbell. This procedure was repeated until maximal power and force at maximal power were recorded. Power was measured by means of a linear encoder (SmartCoach Power Encoder, SmartCoach Europe, Stockholm, Sweden) connected perpendicularly to the barbell of a Smith machine [11]. The interpolation of the points representing the actual power at each step was used to get a second order equation to calculate estimated peak power and the level of force at peak power.

\subsubsection{CMJ}

The CMJ test [12] was performed using a portable force platform (Quattro Jump, Kistler, Winterthur, Switzerland). Each participant performed 3 bilateral single CMJs from a standing position with arms 
akimbo. During the concentric phase of each CMJ, peak power output (PPO), peak force (F) and jump height $(\mathrm{JH})$ were measured. The mean of the three values was used for the analysis.

\subsubsection{Yo-Yo IRL1}

The Yo-Yo IRL1 $[13,14]$ consisted of 20-meter shuttle runs performed at increasing velocities (beginning speed of $10 \mathrm{~km} \cdot \mathrm{h}^{-1}$ ) with $10 \mathrm{~s}$ of active recovery between runs until exhaustion. The test concluded when participants failed to complete the distance on time twice with acoustic pacer (objective evaluation) or due to volitional fatigue (subjective evaluation). The total distance covered during Yo-Yo IRL1 was considered as the test outcome [14]. A rating of perceived exertion by the Borg CR-10 scale was recorded at the end of the test.

\subsubsection{CTT}

Participants were required to execute the maximal number of repetitions within $1 \mathrm{~min}$ in different exercises (operationally defined as RM) (separated by 3 min of passive recovery) [1]. Exercises were: carrying a $70 \mathrm{~kg}$ manikin (simulating an injured individual) for $20 \mathrm{~m}$ as many time as possible (TIM), $20 \mathrm{~m}$ shuttle run (SR) (one way front run, return backward run and arrival in prone position), sit-ups, push-ups (start and arrival with chest touching the ground), squat (SQ) (lifting $20 \mathrm{~kg}$ moved from the ground to the head with outstretched arms) and pull-ups (PLU) (start with full extension of the arms, arriving to the chin over the bar).

\subsubsection{MT}

The MT consisted of several physical evaluations, each one yielding a result expressed as number of repetitions, distance, height, or time. The tests were: a $2000 \mathrm{~m}$ run to complete as fast as possible, transport of the wounded (TW) (in which a $70 \mathrm{~kg}$ manikin had to be dragged for $40 \mathrm{~m}$ as fast as possible), lifting the bomb (LB) (moving a weight of $20 \mathrm{~kg}$ from the ground up to the head with arms extended as much times as possible), rope climb (RC) (the subject had to climb on a $4 \mathrm{~m}$ rope as fast as possible with the help of the lower limbs), loading of the machine gun (LMG) (the maximal number of repetitions of specific movement of the military discipline, comparable to the movement performed during the rowing exercise with dumbbell), high jump (HJ) (maximum height of jumping a pole). For each test, a score was assigned as expressed in the official evaluation table of entrance test for the military academy (Table 1). Scores were summed up in order to assess the total score for the MT.

Table 1. Official evaluation table of entrance tests for the military academy.

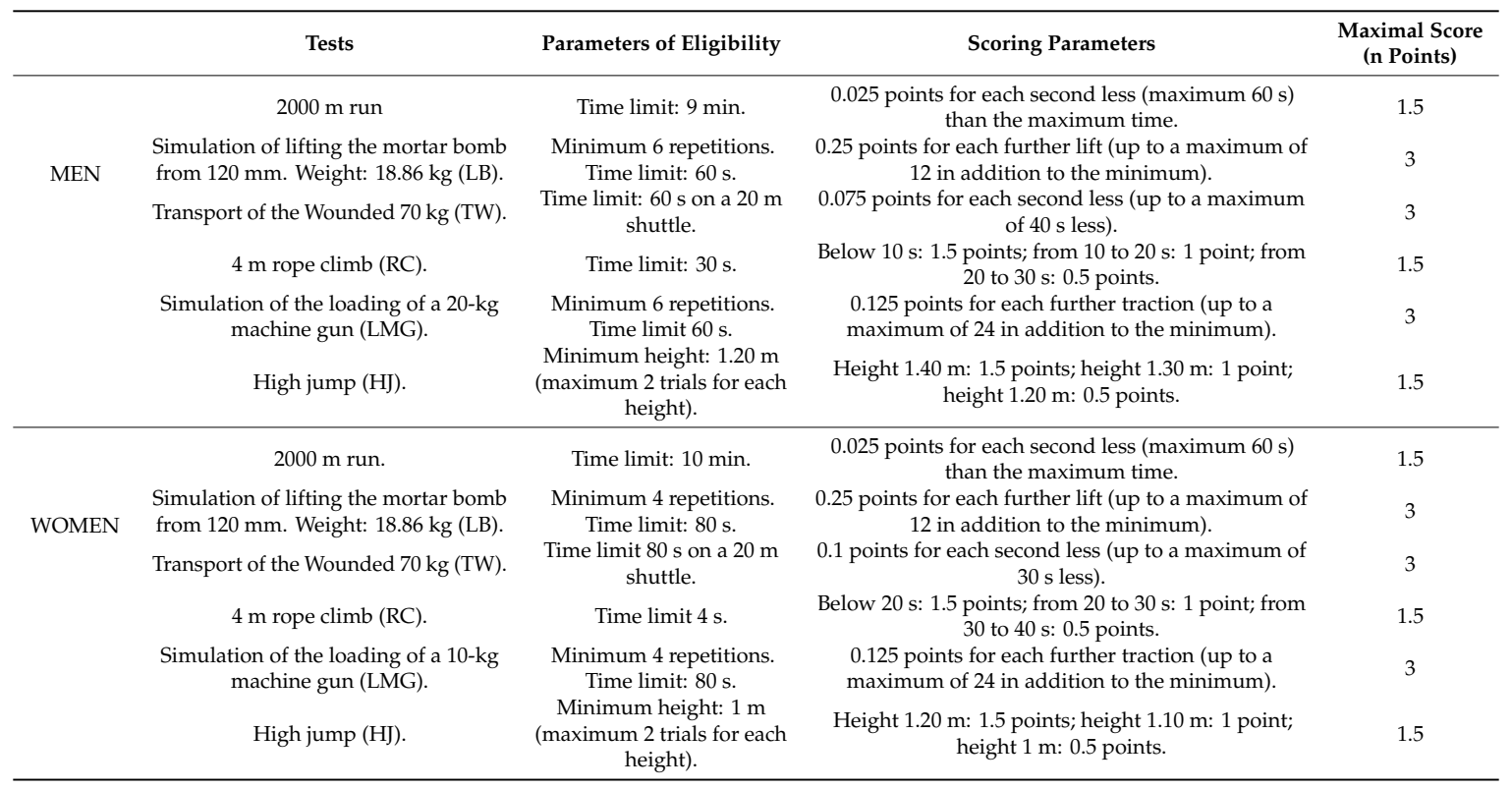




\subsubsection{Session-RPE}

The Session-RPE method takes into consideration the intensity and the duration of the lesson, in order to calculate the training load [15]. At the end of each lesson, participants of both groups reported the perceived RPE, and the training load was evaluated by multiplying the given value for the minutes of the lesson. In this way, it is possible to evaluate the internal load of each participant.

\subsubsection{Nasa Task Load Index (Nasa TLX)}

To assess possible differences in terms of perceived workload relative to daily activity, the Nasa TLX [16] was administered to 16 students of the Teulié Military School and 13 students of the same age at another scientific high school in Milan. The questionnaire was performed after a typical school day for both institutes. The questions deal with the overall experience of workload that students experience in their typical school day.

\subsubsection{Training Interventions}

The two groups underwent eight weeks of training intervention, with two sessions per week. In the first session of the week, the participants of the experimental group performed a training program aimed at improving strength and power. After a 5-min warm-up with mobility exercises, participants performed 12 repetitions with $50 \%$ of their bodyweight at the bench press exercise and half back squat exercise. After that, they performed 3 sets of 10 repetitions at the bench press using the load referred to as Force $(\mathrm{kg})$ expressed at maximal Power, recorded in the BPT, and 4 sets of 6 repetitions of half back squat with a load of $60 \%$ of the maximal strength recorded in the CMJ. In the second session of the week, the participants took part in a circuit training program composed of the same exercises as the CTT ( 2 sets of circuits with $1 \mathrm{~min}$ of recovery between each exercise). In the first, third, fifth and seventh week, the load was 50\% of RM, whereas in the second, fourth, sixth and eighth week it was $70 \%$ of RM. The participants of the control group underwent a traditional physical education based on track-and-field sport disciplines (such as special runs and high jump) and volleyball. Thirty minutes after the end of each session, the participants provided their rating of perceived exertion relative to the entire session, using the Borg CR-10 scale according to the Session-RPE method $[17,18]$. Participants in the study who did not take part at least in $75 \%$ of the training sessions were excluded from the data analysis.

\subsection{Phenomenological-Qualitative Approach, Process Referred}

\subsubsection{Pedagogical Principles}

The experimental project proposed through this study, in harmony with the aims of an action-research [19], goes beyond obtaining research results to improve understanding of a determined knowledge and discover simply whether an approach works better than another one. Rather, this project aims to ensure sustainability of research in the field of education through the analysis of a specific field of experience to introduce a contribution to verify improvements in the interpretation of exercise sciences, and their cultural utility in a very particular context such as military high schools. Within this educational project, the research-action perspective is as a field-based experience allowing the subjects to be actors of their training process [19]. In this framework, the proposal should be intended as perfectly integrated into a school project to the national indications for the high school curriculum, established by the Ministry of Public Education. Table 2 shows the educational design that has allowed the practical application of this research $[20,21]$.

\subsubsection{Criteria and Empirical Observation Sheets}

To evaluate the acquisition of educational objectives such as social skills and collaboration, motivation and understanding, sixteen random subjects from the experimental group were observed 
and evaluated with an observation grid (Planned Activity Check (PLACHECK) system). This sub-group of sixteen students was divided into two groups for a more correct and precise analysis and each group was observed in two different lessons (once with circuit training and once in exercises with barbell). Three different observers completed the grid evaluating the same sixteen subjects in three different days, in order to assess the within-subject and between-subjects reliability. The observation indicators were the following: the pupil is motivated and engaged in the proposed activity; the student demonstrates that he or she has understood the information, uses the advice given by the teacher and gives advice for a partner when assisting someone; the student is available to collaborate with the partner during the execution of the exercises. The grid was compiled indicating Yes/No according to the response (or lack thereof) of what is expressed by the indicator. The Planned Activity Check system (PLACHECK) [22,23] was used to register appropriate or inappropriate student behavior during sessions [23]. The PLACHECK system [24] is a sampler procedure which is used to register group behavior. This system makes it possible to verify activities which have been programmed for group work, comparing the total number of individuals forming the group over a specific time period. The reported data are portrayed as a percentage. The inter-observer rate obtained for the PLACHECK system was $94.9 \%$ [25]. In particular, the evaluation was positive (Yes) for motivation when the student had participated with commitment and interest in the lesson (the student actively participated in the motor activity by carrying out the planned work); for understanding when the student demonstrates that he or she has understood a piece of information and has acquired a concept (to correct himself or herself, after performing an exercise, the student resorted to the teacher's advice or gave effective and useful feed-back to the partner; the student proves to have read some recommended in-depth papers). Positive evaluation was also given for collaboration when a student assisted his companions in carrying out the exercises and had a collaborative attitude (he has given help putting himself in the correct position to assist his partner, guaranteeing his active presence for the duration of the exercise).

\subsubsection{Interviews with Students}

To complete the feedback of the experience, the same students from the observation grid were interviewed and asked the following questions by means of semi-structured interviews [26]: What did you like about the lessons given and why? What didn't you like and why? After collecting and analyzing the results of the interviews of the experimental group, in order to acquire further information on the experience and research-action experience carried out by the students, the same questions were asked to 16 random subjects from the control group. The data were collected by three external interviewers and were analyzed identifying a coding process [27]. From the semi-structured interviews, emergent features of students' perception appeared and were analyzed. Firstly, a line-by-line coding procedure was performed to obtain specific labels; secondly, common labels were created and counted; lastly, the relationships between each category were examined, creating a diagram according to the grounded theory method [28]. The overall experimental design is shown in Figure 1.

\subsection{Statistical Analysis}

Data are reported as means \pm standard deviations (SD). The Shapiro-Wilk normality test was used to verify the normality of the data distribution. A Bayesian-like approach, the magnitude-based inference (MBI), was used to analyze the data according to Hopkins et al. [29]. All data have been log-transformed to reduce bias [29] The analysis has compared results for experimental and control group in pre- and post-intervention, then the differences between pre and post for both groups were analyzed. The main outcome of the MBI statistics is expressed as the chance that a true effect of the experimental intervention occurs. All analyzed data were evaluated according to established criteria: $<1 \%$, almost certainly not; $1-5 \%$, very unlikely; $5-25 \%$, unlikely; $25-75 \%$, possible; $75-95 \%$, likely; 95-99\%, very likely; >99\%, almost certain (Hopkins et al., 2009). A clinically unclear effect (unclear) is defined by a probability $>5 \%$ for both harmful and beneficial effects. In this case, it is impossible to define the true effect. In order to analyze the reliability of qualitative data, the Cochran's 
Q test was applied in the within-subject analysis and the extended chi-square test was applied in the between-subjects analysis. The $\alpha$-value was set to 0.05 . The MBI approach used to analyze the data has the advantage of detecting the effects of a treatment even with a small sample size (i.e., approximately one third compared to the traditional method) [30]. Considering a medium effect size $(d=0.6)$, that was the one used as standardized threshold value for the MBI, a power of $0.9(1-\beta)$, and an $\alpha$ error of 0.05 , the total sample size required for a pairwise comparison was 32. Sample size and power calculation were carried out using G-Power (Version 3.1.9.2, Franz Fraul, University of Kiel, Germany).

Table 2. Educational design (program for competences) [31].

\begin{tabular}{|c|c|}
\hline Title of Disciplinary Learning Unit & Research-Action as a Basic Element of an Innovative School Motor Culture. \\
\hline European skills developed & $\begin{array}{l}\text { Digital skills; learning to learn; social and civic skills; initiative spirit and entrepreneurship; } \\
\text { awareness and cultural expression. }\end{array}$ \\
\hline Citizenship skills developed to create a competent student & $\begin{array}{l}\text { Learning to learn; designing; communicating; collaborating and participating; } \\
\text { acting independently and responsibly; problems solving; identifying links and relationships; } \\
\text { acquiring and interpreting information. }\end{array}$ \\
\hline Learning objectives (Ministerial Italian School Program) & $\begin{array}{l}\text { Self-perception and functional development of motor skills; health, wellness and prevention; } \\
\text { relationship with the natural and technological environment. }\end{array}$ \\
\hline $\begin{array}{l}\text { Goals for the development of competences } \\
\text { (Ministerial Italian School Program) }\end{array}$ & $\begin{array}{l}\text { Awareness of your body through the stimulation of motor skills both as a specific objective } \\
\text { and as a condition for reaching higher levels of ability and motor performance; knowing how } \\
\text { to act responsibly, reasoning about what you are putting into action and being able to } \\
\text { analyze your own and others' performance, identifying positive and negative aspects; } \\
\text { working both in group and individually to learn cooperating with others following shared } \\
\text { rules for a common goal; acquiring knowledge of methods, work techniques and experiences } \\
\text { for the purpose of acquiring the awareness and the ability to organize autonomously one's } \\
\text { own physical development and maintenance plan with the goal of a performance; maturing } \\
\text { the need to reach and maintain an adequate level of psychophysical fitness to be able to face } \\
\text { every day needs as study, future work, sport and leisure; acquiring opportunities to be } \\
\text { familiarized with and practice the use of innovative technologies and tools applicable to } \\
\text { activities and other disciplines. }\end{array}$ \\
\hline Reality task (based on military academy test) & $\begin{array}{l}\text { The reality task was used to create a learning situation that aimed to develop abilities in an } \\
\text { experimental way. The reality task, regardless of results, highlights multi-disciplinary } \\
\text { theoretical references that corroborate the student experience and knowledge. Adding an } \\
\text { appropriate reflective activity to this process, the reality task gives a greater value to learning } \\
\text { that would not be possible with an aseptic research without a direct and reflective } \\
\text { involvement of the students. }\end{array}$ \\
\hline Research-action & $\begin{array}{l}\text { The style of teaching assets based on comparison of ideas and strategies represents a useful } \\
\text { element to activate the cognitive tools intended to direct the subjects to a process of } \\
\text { research-action in which they feel empowered and like leaders. This is a "research in the } \\
\text { research", with the objective of a project for the creation of high cultural and professional } \\
\text { profiles that can adapt situationally to the requests for a double and complex reality, } \\
\text { the military and the high school, in which body culture plays a relevant role. }\end{array}$ \\
\hline Specific learning objectives: knowledge & $\begin{array}{l}\text { Knowing the possible interactions between the different components influencing motor } \\
\text { performance; knowing the effects of the practice exercises; knowing technological tools } \\
\text { useful for a precise monitoring of the motor capabilities to develop; knowing the criteria } \\
\text { followed in experimental research; knowing the criteria for organizing a motor project aimed } \\
\text { at performance; knowing the relationship between the qualities developed through the } \\
\text { training and performance of military tests also through analyzing scientific literature. }\end{array}$ \\
\hline Specific learning objectives: skills & $\begin{array}{l}\text { Ability based on the capacity to perceive your body and recognize fatigue, analyzing the } \\
\text { effects of training through the use of perception of effort stairs; using consciously and } \\
\text { appropriately the exercises useful to develop the different capacities; recognizing the } \\
\text { methodological path adopted in the research; ability to perform correctly the monitoring } \\
\text { exercises; ability based on the capacity to perform exercises correctly and safely to avoid } \\
\text { injury and micro-traumas during exercises; ability based on the capacity for adequate work } \\
\text { in an appropriate manner and adequate organization of training sessions; ability to organize } \\
\text { work according to the environment in which we act, the time available and the objectives; } \\
\text { ability to adopt the specific procedures for work in circuit and with weights; ability to relate } \\
\text { with the technological environment in the use of specific tools for monitoring strength and } \\
\text { power of lower and upper limbs. }\end{array}$ \\
\hline $\begin{array}{l}\text { Cultural axes involved (chosen in the Ministerial Italian } \\
\text { School Program) }\end{array}$ & $\begin{array}{l}\text { Mathematical axis: knowing how to analyze data and interpret them, developing deductions } \\
\text { and reasons with the aid of graphical representations, consciously using potentiality offered } \\
\text { by specific informatics applications.Scientific-technological axis: observing, describing and } \\
\text { analyzing phenomena belonging to reality and recognizing systems and complex concepts in } \\
\text { various forms. Being aware of the potentialities and limitations of technology in the cultural } \\
\text { and social context in which they are applied.Social-historical axis: understanding the change } \\
\text { and diversity in historical times of the body concept in a diachronic dimension through the } \\
\text { comparison between periods and in a synchronous dimension between different } \\
\text { cultural areas. }\end{array}$ \\
\hline
\end{tabular}




\section{Results}

\subsection{Functional-Quantitative Approach, Product Referred}

\subsubsection{Bench Press Test, CMJ, Yo-Yo IRL1, Circuit Training Test, Military Tests}

The descriptive statistics, magnitude-based inferences, and effect sizes of the bench press test, countermovement jump test and Yo-Yo IRL1 are shown in Table 3. The descriptive statistics, magnitude-based inferences, and effect sizes of the circuit training test are shown in Table 4 . The descriptive statistics, magnitude based inferences, and effect sizes of the military tests are shown in Table 5.

\subsubsection{Session-RPE}

The Session-RPE of the 16 training sessions in the experimental and control groups are shown in Figure 2. In the Session-RPE analysis, 137 of 960 values of Session-RPE are missing data (14.3\%). In order to perform statistical analysis, the missing values were substituted by values obtained using the mean method (version 20.0, IBM SPSS Statistics, Chicago, IL, USA). The session RPE was higher in the experimental group than in the control group in 12 out of 16 sessions. In particular, sessions 1 , $3,4,5,7,8,9,11,12,13,15$ were found to be the most likely positive and session 14 was very likely positive. Conversely, sessions 6 and 16 were found to be the most likely negative and the comparisons in sessions 2 and 10 were unclear.

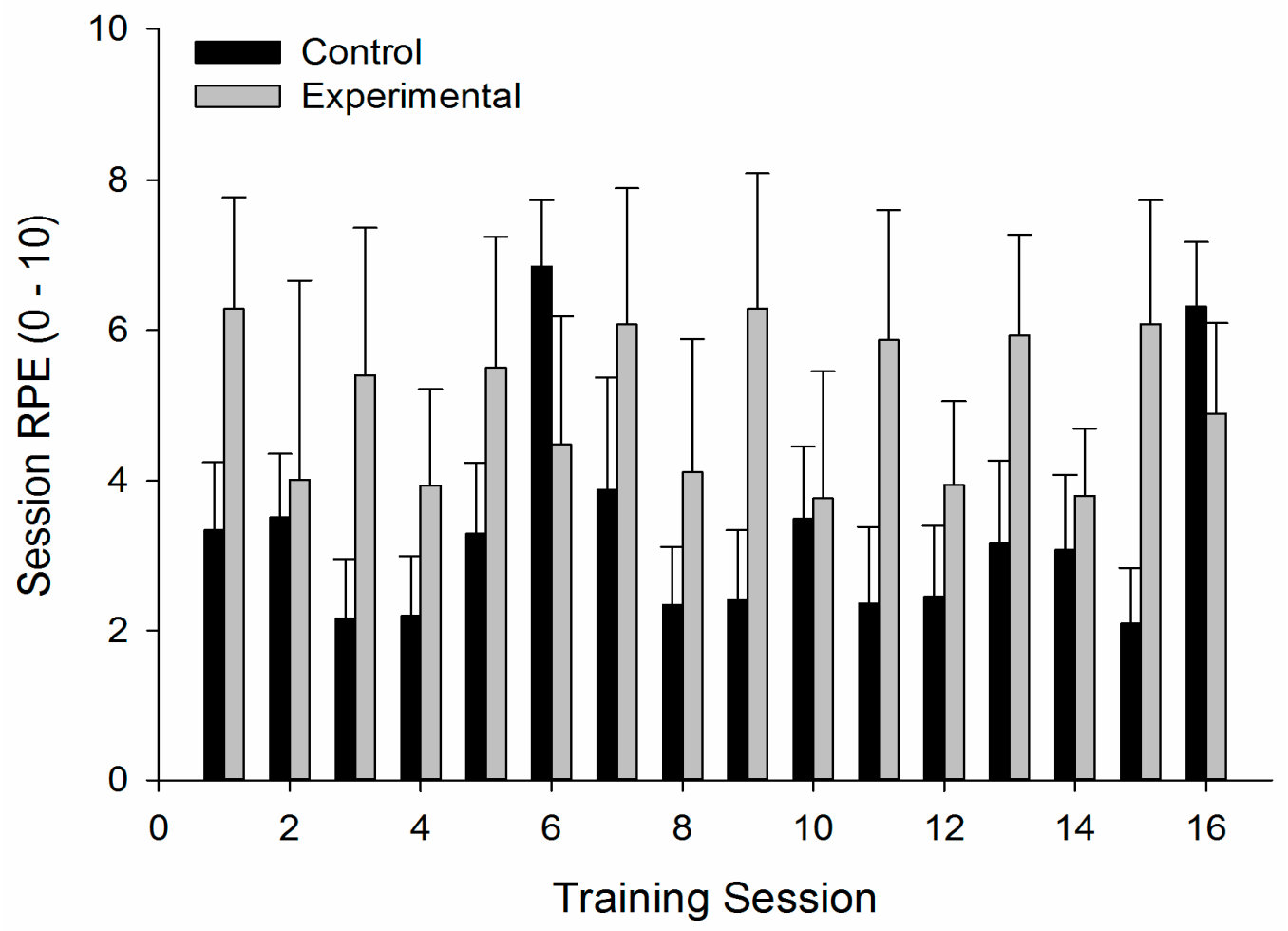

Figure 2. Session-RPE of the 16 training sessions in the experimental and control groups. 
Table 3. Descriptive statistics, magnitude-based inferences, and effect sizes of the bench press test, countermovement jump test and Yo-Yo IRL1.

\begin{tabular}{|c|c|c|c|c|c|c|c|c|c|c|c|c|c|c|}
\hline \multirow[b]{2}{*}{ Test } & \multirow[b]{2}{*}{ Variable } & \multicolumn{4}{|c|}{ Mean \pm SD } & \multicolumn{5}{|c|}{ Magnitude-Based Inference } & \multicolumn{4}{|c|}{ Effect Size (Cohen's d) } \\
\hline & & CG Pre & EG Pre & CG Post & EG Post & $\begin{array}{c}\text { CG Pre vs. } \\
\text { EG Pre }\end{array}$ & $\begin{array}{l}\text { CG Post vs. } \\
\text { EG Post }\end{array}$ & $\begin{array}{l}\text { CG Pre vs. } \\
\text { CG Post }\end{array}$ & $\begin{array}{l}\text { EG Pre vs. } \\
\text { EG Post }\end{array}$ & Effect & $\begin{array}{c}\text { CG Pre vs. } \\
\text { EG Pre }\end{array}$ & $\begin{array}{l}\text { CG Post vs. } \\
\text { EG Post }\end{array}$ & $\begin{array}{l}\text { CG Pre vs. } \\
\text { CG Post }\end{array}$ & $\begin{array}{c}\text { EG Pre vs. } \\
\text { EG Post }\end{array}$ \\
\hline \multirow{2}{*}{$\begin{array}{c}\text { Bench press } \\
\text { test }\end{array}$} & $\mathrm{P}(\mathrm{W})$ & $\begin{array}{c}260.7 \pm \\
104.5\end{array}$ & $\begin{array}{c}263.7 \pm \\
93.4\end{array}$ & $\begin{array}{c}264.9 \pm \\
108.7\end{array}$ & $\begin{array}{c}265.5 \pm \\
89.8\end{array}$ & $\begin{array}{c}\text { Possibly } \\
\text { trivial }\end{array}$ & $\begin{array}{c}\text { Possibly } \\
\text { trivial }\end{array}$ & $\begin{array}{c}\text { Very likely } \\
\text { trivial }\end{array}$ & $\begin{array}{c}\text { Most likely } \\
\text { trivial }\end{array}$ & $\begin{array}{l}\text { Very likely } \\
\text { trivial }\end{array}$ & 0.03 & 0.01 & 0.05 & 0.03 \\
\hline & $\mathrm{F}(\mathrm{N})$ & $\begin{array}{c}37.3 \pm \\
13.0\end{array}$ & $\begin{array}{c}37.0 \pm \\
10.4\end{array}$ & $\begin{array}{c}38.5 \pm \\
13.8\end{array}$ & $\begin{array}{c}36.8 \pm \\
9.8\end{array}$ & $\begin{array}{c}\text { Possibly } \\
\text { trivial }\end{array}$ & $\begin{array}{c}\text { Possibly } \\
\text { trivial }\end{array}$ & $\begin{array}{c}\text { Most likely } \\
\text { trivial }\end{array}$ & $\begin{array}{l}\text { Possibly } \\
\text { positive }\end{array}$ & $\begin{array}{l}\text { Possibly } \\
\text { positive }\end{array}$ & -0.03 & -0.15 & 0.13 & -0.01 \\
\hline \multirow{3}{*}{ CMJ } & $\mathrm{PPO}(\mathrm{W})$ & $\begin{array}{c}3012.2 \pm \\
589.9\end{array}$ & $\begin{array}{c}3264.5 \pm \\
877.2\end{array}$ & $\begin{array}{c}3038.7 \pm \\
593.8\end{array}$ & $\begin{array}{c}3219.8 \pm \\
736.0\end{array}$ & Unclear & Unclear & $\begin{array}{c}\text { Most likely } \\
\text { trivial }\end{array}$ & $\begin{array}{c}\text { Very likely } \\
\text { trivial }\end{array}$ & Unclear & -0.29 & -0.20 & -0.09 & 0.08 \\
\hline & $\mathrm{F}(\mathrm{N})$ & $\begin{array}{c}1690.1 \pm \\
305.8\end{array}$ & $\begin{array}{c}1769.8 \pm \\
322.6\end{array}$ & $\begin{array}{c}1583.2 \pm \\
250.8\end{array}$ & $\begin{array}{c}1741.3 \pm \\
326.4\end{array}$ & $\begin{array}{l}\text { Possibly } \\
\text { positive }\end{array}$ & Likely trivial & $\begin{array}{l}\text { Possibly } \\
\text { positive }\end{array}$ & $\begin{array}{l}\text { Possibly } \\
\text { positive }\end{array}$ & $\begin{array}{l}\text { Possibly } \\
\text { positive }\end{array}$ & 0.25 & 0.54 & -0.54 & -0.12 \\
\hline & $\mathrm{JH}(\mathrm{cm})$ & $\begin{array}{c}40.7 \pm \\
7.1\end{array}$ & $\begin{array}{c}41.0 \pm \\
7.6\end{array}$ & $\begin{array}{c}39.3 \pm \\
7.1\end{array}$ & $\begin{array}{c}39.5 \pm \\
7.40\end{array}$ & $\begin{array}{l}\text { Possibly } \\
\text { positive }\end{array}$ & $\begin{array}{c}\text { Very likely } \\
\text { trivial }\end{array}$ & $\begin{array}{l}\text { Possibly } \\
\text { positive }\end{array}$ & $\begin{array}{l}\text { Possibly } \\
\text { positive }\end{array}$ & $\begin{array}{c}\text { Most likely } \\
\text { trivial }\end{array}$ & 0.05 & 0.02 & -0.26 & -0.29 \\
\hline Yo-Yo IRL1 & Distance $(\mathrm{m})$ & $\begin{array}{c}924.2 \pm \\
475.5\end{array}$ & $\begin{array}{c}1120.0 \pm \\
585.2\end{array}$ & $\begin{array}{c}753.7 \pm \\
364.5\end{array}$ & $\begin{array}{c}972.2 \pm \\
460.0\end{array}$ & $\begin{array}{l}\text { Possibly } \\
\text { positive }\end{array}$ & $\begin{array}{c}\text { Likely } \\
\text { positive }\end{array}$ & $\begin{array}{l}\text { Possibly } \\
\text { positive }\end{array}$ & $\begin{array}{c}\text { Likely } \\
\text { positive }\end{array}$ & Likely trivial & 0.36 & 0.52 & -0.57 & -0.40 \\
\hline
\end{tabular}

Values are mean \pm SD. CG: control group. EG: experimental group. Bench press test: power (P), force (N). Countermovement jump (CMJ): peak power output (PPO); peak force (F); jump height (JH). Yo-Yo IRL1: distance. Established criteria of MBI: <1\%, almost certainly not; 1-5\%, very unlikely; 5-25\%, unlikely; 25-75\%, possibly; 75-95\%, likely; $95-99 \%$, very likely; $>99 \%$, almost certain; no percentage prevalence, unclear. Positive $=$ beneficial effect, Negative $=$ harmful effect, Trivial $=$ no effect. 
Table 4. Descriptive statistics, magnitude-based inferences, and effect sizes of the circuit training test.

\begin{tabular}{|c|c|c|c|c|c|c|c|c|c|c|c|c|c|c|}
\hline \multirow[b]{2}{*}{ Test } & \multirow[b]{2}{*}{ Variable } & \multicolumn{4}{|c|}{ Mean \pm SD } & \multicolumn{5}{|c|}{ Magnitude-Based Inference } & \multicolumn{4}{|c|}{ Effect Size (Cohen's d) } \\
\hline & & CG Pre & EG Pre & CG Post & EG Post & $\begin{array}{l}\text { CG Pre vs. } \\
\text { EG Pre }\end{array}$ & $\begin{array}{l}\text { CG Post vs. } \\
\text { EG Post }\end{array}$ & $\begin{array}{l}\text { CG Pre vs. } \\
\text { CG Post }\end{array}$ & $\begin{array}{c}\text { EG Pre vs. } \\
\text { EG Post }\end{array}$ & Effect & $\begin{array}{c}\text { CG Pre vs. } \\
\text { EG Pre }\end{array}$ & $\begin{array}{l}\text { CG Post vs. } \\
\text { EG Post }\end{array}$ & $\begin{array}{l}\text { CG Pre vs. } \\
\text { CG Post }\end{array}$ & $\begin{array}{c}\text { EG Pre vs. } \\
\text { EG Post }\end{array}$ \\
\hline \multirow{6}{*}{$\begin{array}{c}\text { Circuit } \\
\text { Training Test }\end{array}$} & TIM (rep) & $\begin{array}{c}62.0 \pm \\
13.2\end{array}$ & $\begin{array}{c}58.3 \pm \\
18.0\end{array}$ & $\begin{array}{c}66.8 \pm \\
14.3\end{array}$ & $\begin{array}{c}70.4 \pm \\
17.2\end{array}$ & $\begin{array}{c}\text { Very Likely } \\
\text { Trivial }\end{array}$ & $\begin{array}{l}\text { Unlikely } \\
\text { Positive }\end{array}$ & $\begin{array}{c}\text { Very Likely } \\
\text { Trivial }\end{array}$ & $\begin{array}{l}\text { Possibly } \\
\text { Positive }\end{array}$ & Likely Trivial & -0.01 & 0.41 & 0.43 & 0.98 \\
\hline & SR (rep) & $8.2 \pm 1.4$ & $7.9 \pm 1.5$ & $8.8 \pm 1.2$ & $9.0 \pm 1.0$ & $\begin{array}{c}\text { Very Likely } \\
\text { Trivial }\end{array}$ & $\begin{array}{l}\text { Possibly } \\
\text { Positive }\end{array}$ & $\begin{array}{l}\text { Possibly } \\
\text { Positive }\end{array}$ & $\begin{array}{c}\text { Likely } \\
\text { Positive }\end{array}$ & Likely Trivial & 0.04 & 0.42 & 0.67 & 1.39 \\
\hline & SU (rep) & $\begin{array}{c}44.5 \pm \\
9,4\end{array}$ & $\begin{array}{c}43.0 \pm \\
9.4\end{array}$ & $\begin{array}{c}51.0 \pm \\
7.3\end{array}$ & $\begin{array}{c}48.5 \pm \\
6.9\end{array}$ & $\begin{array}{l}\text { Most } \\
\text { Likely } \\
\text { Trivial }\end{array}$ & $\begin{array}{l}\text { Most Likely } \\
\text { Trivial }\end{array}$ & $\begin{array}{l}\text { Likely } \\
\text { Positive }\end{array}$ & $\begin{array}{l}\text { Likely } \\
\text { Positive }\end{array}$ & $\begin{array}{l}\text { Most Likely } \\
\text { Trivial }\end{array}$ & -0.04 & -0.22 & 1.08 & 1.09 \\
\hline & PU (rep) & $\begin{array}{c}37.4 \pm \\
15.9\end{array}$ & $\begin{array}{c}38.5 \pm \\
12.9\end{array}$ & $\begin{array}{c}46.1 \pm \\
15.2\end{array}$ & $\begin{array}{l}45.2 \pm \\
15.1\end{array}$ & $\begin{array}{l}\text { Possibly } \\
\text { Positive }\end{array}$ & $\begin{array}{l}\text { Possibly } \\
\text { Positive }\end{array}$ & \multirow{3}{*}{$\begin{array}{l}\text { Possibly } \\
\text { Positive } \\
\text { Likely } \\
\text { Positive } \\
\text { Likely } \\
\text { Positive }\end{array}$} & $\begin{array}{l}\text { Possibly } \\
\text { Positive }\end{array}$ & $\begin{array}{l}\text { Very Likely } \\
\text { Trivial }\end{array}$ & 0.39 & 0.28 & 0.69 & 0.78 \\
\hline & SQ (rep) & $\begin{array}{c}20.9 \pm \\
7.1\end{array}$ & $\begin{array}{c}17.8 \pm \\
6.6\end{array}$ & $\begin{array}{c}23.9 \pm \\
5.7\end{array}$ & $\begin{array}{c}24.0 \pm \\
8.0\end{array}$ & $\begin{array}{l}\text { Possibly } \\
\text { Negative }\end{array}$ & Likely Trivial & & $\begin{array}{l}\text { Possibly } \\
\text { Positive }\end{array}$ & Likely Trivial & -0.28 & 0.07 & 0.70 & 1.08 \\
\hline & PLU (rep) & $\begin{array}{c}11.5 \pm \\
9.6\end{array}$ & $\begin{array}{c}10.1 \pm \\
7.5\end{array}$ & $\begin{array}{c}14.9 \pm \\
10.9\end{array}$ & $\begin{array}{c}13.4 \pm \\
8.5\end{array}$ & $\begin{array}{l}\text { Likely } \\
\text { Trivial }\end{array}$ & Likely Trivial & & $\begin{array}{c}\text { Likely } \\
\text { Positive }\end{array}$ & Likely Trivial & -0.03 & 0.03 & 0.32 & 0.52 \\
\hline
\end{tabular}

Values are mean \pm SD. CG: control group. EG: experimental group. Circuit training test: Transport of injured manikin (TIM), shuttle run (SR), sit-up (SU), push-up (PU), squat (SQ),

pull-up (PLU). Established criteria of MBI: <1\%, almost certainly not; 1-5\%, very unlikely; 5-25\%, unlikely; 25-75\%, possibly; 75-95\%, likely; $95-99 \%$, very likely; >99\%, almost certain;

no percentage prevalence, unclear. Positive $=$ beneficial effect, Negative $=$ harmful effect, Trivial $=$ no effect. 
Table 5. Descriptive statistics, magnitude-based inferences, and effect sizes of the military tests.

\begin{tabular}{|c|c|c|c|c|c|c|c|c|c|c|c|c|c|c|}
\hline \multirow[b]{2}{*}{ Test } & \multirow[b]{2}{*}{ Variable } & \multicolumn{4}{|c|}{ Mean \pm SD } & \multicolumn{5}{|c|}{ Magnitude-Based Inference } & \multicolumn{4}{|c|}{ Effect Size (Cohen's d) } \\
\hline & & CG Pre & EG Pre & CG Post & EG Post & $\begin{array}{c}\text { CG Pre vs. } \\
\text { EG Pre }\end{array}$ & $\begin{array}{l}\text { CG Post vs. } \\
\text { EG Post }\end{array}$ & $\begin{array}{c}\text { CG Pre vs. } \\
\text { CG Post }\end{array}$ & $\begin{array}{c}\text { EG Pre vs. } \\
\text { EG Post }\end{array}$ & Effect & $\begin{array}{c}\text { CG Pre vs. } \\
\text { EG Pre }\end{array}$ & $\begin{array}{l}\text { CG Post vs. } \\
\text { EG Post }\end{array}$ & $\begin{array}{c}\text { CG Pre vs. } \\
\text { CG Post }\end{array}$ & $\begin{array}{c}\text { EG Pre vs } \\
\text { EG Post }\end{array}$ \\
\hline \multirow{7}{*}{ Military Tests } & $2000 \mathrm{~m}$ run (s) & $\begin{array}{c}529.5 \pm \\
55.8\end{array}$ & $\begin{array}{c}515.1 \pm \\
42.9\end{array}$ & $\begin{array}{c}494.1 \pm \\
52.4\end{array}$ & $\begin{array}{c}451.5 \pm \\
136.4\end{array}$ & $\begin{array}{c}\text { Very Likely } \\
\text { Trivial }\end{array}$ & $\begin{array}{c}\text { Very Likely } \\
\text { Trivial }\end{array}$ & $\begin{array}{l}\text { Possibly } \\
\text { Negative }\end{array}$ & $\begin{array}{l}\text { Possibly } \\
\text { Negative }\end{array}$ & $\begin{array}{l}\text { Very Likely } \\
\text { Trivial }\end{array}$ & -0.29 & -0.39 & -0.91 & -0.89 \\
\hline & LB (rep) & $\begin{array}{c}13.39 \pm \\
6.96\end{array}$ & $\begin{array}{c}13.58 \pm \\
6.85\end{array}$ & $\begin{array}{l}6.79 \pm \\
8.35\end{array}$ & $\begin{array}{c}10.00 \pm \\
8.57\end{array}$ & Unclear & Likely Trivial & $\begin{array}{l}\text { Most } \\
\text { Likely } \\
\text { Trivial }\end{array}$ & $\begin{array}{l}\text { Most } \\
\text { Likely } \\
\text { Trivial }\end{array}$ & $\begin{array}{c}\text { Very Likely } \\
\text { Trivial }\end{array}$ & -0.04 & -0.11 & 0.01 & 0.41 \\
\hline & TW (s) & $\begin{array}{c}33.8 \pm \\
6.9\end{array}$ & $\begin{array}{c}34.1 \pm \\
10.0\end{array}$ & $\begin{array}{c}27.9 \pm \\
6.5\end{array}$ & $\begin{array}{c}28.4 \pm \\
9.1\end{array}$ & $\begin{array}{l}\text { Likely } \\
\text { Trivial }\end{array}$ & Likely Trivial & $\begin{array}{l}\text { Likely } \\
\text { Negative }\end{array}$ & $\begin{array}{l}\text { Possibly } \\
\text { Negative }\end{array}$ & Likely Trivial & 0.03 & 0.06 & 0.08 & 0.03 \\
\hline & $\mathrm{RC}(\mathrm{s})$ & $\begin{array}{c}19.14 \pm \\
6.71\end{array}$ & $\begin{array}{c}17.84 \pm \\
5.92\end{array}$ & $\begin{array}{c}19.37 \pm \\
7.51\end{array}$ & $\begin{array}{c}16.93 \pm \\
5.47\end{array}$ & $\begin{array}{l}\text { Likely } \\
\text { Trivial }\end{array}$ & $\begin{array}{l}\text { Possibly } \\
\text { Negative }\end{array}$ & $\begin{array}{l}\text { Most } \\
\text { Likely } \\
\text { Trivial }\end{array}$ & $\begin{array}{l}\text { Most } \\
\text { Likely } \\
\text { Trivial }\end{array}$ & $\begin{array}{c}\text { Most Likely } \\
\text { Trivial }\end{array}$ & -0.23 & -0.49 & 0.06 & -0.25 \\
\hline & LMG (rep) & $\begin{array}{c}18.3 \pm \\
6.6\end{array}$ & $\begin{array}{c}23.5 \pm \\
5.1\end{array}$ & $\begin{array}{c}23.5 \pm \\
5.5\end{array}$ & $\begin{array}{c}25.2 \pm \\
6.3\end{array}$ & $\begin{array}{l}\text { Possibly } \\
\text { Positive }\end{array}$ & Likely Trivial & $\begin{array}{c}\text { Likely } \\
\text { Positive }\end{array}$ & $\begin{array}{c}\text { Very Likely } \\
\text { Trivial }\end{array}$ & $\begin{array}{l}\text { Possibly } \\
\text { Negative }\end{array}$ & 0.90 & 0.28 & 0.01 & 0.03 \\
\hline & $\mathrm{HJ}(\mathrm{cm})$ & $\begin{array}{c}128.2 \pm \\
15.4\end{array}$ & $\begin{array}{c}129.4 \pm \\
10.7\end{array}$ & $\begin{array}{c}130.9 \pm \\
13.8\end{array}$ & $\begin{array}{c}133.1 \pm \\
10.1\end{array}$ & $\begin{array}{l}\text { Likely } \\
\text { Trivial }\end{array}$ & Likely Trivial & $\begin{array}{l}\text { Most } \\
\text { Likely } \\
\text { Trivial }\end{array}$ & $\begin{array}{l}\text { Most } \\
\text { Likely } \\
\text { Trivial }\end{array}$ & Likely Trivial & 0.09 & 0.24 & -0.10 & 0.09 \\
\hline & TS & $\begin{array}{l}8.92 \pm \\
2.25\end{array}$ & $\begin{array}{c}9.39 \pm \\
2.36\end{array}$ & $\begin{array}{c}6.93 \pm \\
3.38\end{array}$ & $\begin{array}{c}8.71 \pm \\
3.71\end{array}$ & $\begin{array}{l}\text { Likely } \\
\text { Trivial }\end{array}$ & $\begin{array}{l}\text { Possibly } \\
\text { Positive }\end{array}$ & $\begin{array}{l}\text { Likely } \\
\text { Negative }\end{array}$ & $\begin{array}{l}\text { Likely } \\
\text { Trivial }\end{array}$ & Likely Trivial & 0.20 & 0.50 & 0.69 & 0.22 \\
\hline
\end{tabular}

Values are mean \pm SD. CG: control group. EG: experimental group. Military tests: $2000 \mathrm{~m}$ run, lifting the bomb (LB), transport of the wounded (TW), rope climb (RC), loading of the machine gun (LMG), high jump (HJ), total score (TS). Established criteria of MBI: $<1 \%$, almost certainly not; 1-5\%, very unlikely; 5-25\%, unlikely; 25-75\%, possibly; 75-95\%, likely; 95-99\%, very likely; $>99 \%$, almost certain; no percentage prevalence, unclear. Positive = beneficial effect, Negative $=$ harmful effect, Trivial $=$ no effect. 


\subsubsection{Nasa TLX}

The Nasa TLX perceived workloads of Military and High School students are shown in Figure 3. The descriptive statistics, magnitude-based inferences, and effect sizes of the comparisons between Military and High School students are shown in Table 6.

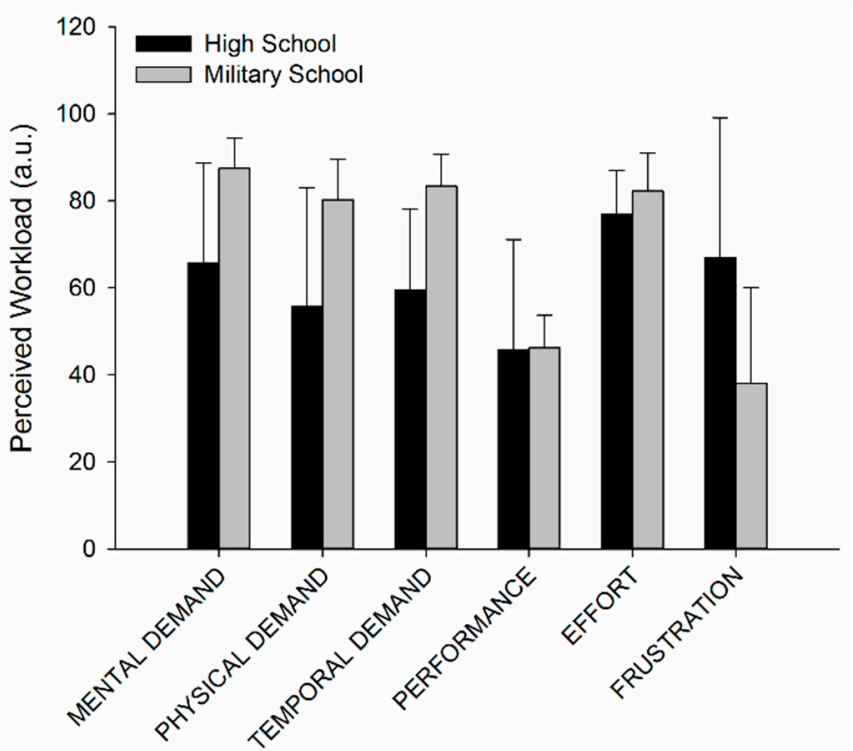

Figure 3. Comparisons of Nasa TLX perceived workload between high school students and military school students.

Table 6. Nasa TLX results.

\begin{tabular}{|c|c|c|c|c|c|c|}
\hline & MD & PD & TD & $\mathbf{P}$ & E & $\mathbf{F}$ \\
\hline Military school students & $87.5 \pm 6.8$ & $80.3 \pm 9.2$ & $83.4 \pm 7.2$ & $46.3 \pm 7.4$ & $82.2 \pm 8.8$ & $38.1 \pm 21.9$ \\
\hline High school students & $65.8 \pm 23.0$ & $55.8 \pm 27.4$ & $59.6 \pm 18.5$ & $45.8 \pm 25.4$ & $76.9 \pm 10.1$ & $66.9 \pm 32.2$ \\
\hline MBI Comparisons & Likely positive & Likely positive & Very Likely positive & Unlikely positive & Possibly positive & Possibly positive \\
\hline ES (Cohen's d) & 1.34 & 1.26 & 1.77 & 0.03 & 0.56 & -1.07 \\
\hline
\end{tabular}

Mental demand (MD), physical demand (PD), temporal demand (TD), performance (P), effort (E) and frustration (F). All data are shown as mean \pm SD. Established criteria of MBI: $<1 \%$, almost certainly not; $1-5 \%$, very unlikely; $5-25 \%$, unlikely; $25-75 \%$, possible; $75-95 \%$, likely; $95-99 \%$, very likely; $>99 \%$, almost certain. Positive = beneficial effect, Negative $=$ harmful effect, Trivial $=$ no effect. Effect sizes (ES) are expressed as Cohen's d values.

\subsection{Phenomenological-Qualitative Approach, Process Referred}

All analyzed data were found reliable in within-subject $(p=0.905$ for motivation; $p=0.584$ for understanding and $p=0.607$ for collaboration) and between-subjects analysis ( $p=0.963$ for motivation; $p=0.848$ for understanding and $p=0.666$ for collaboration). Percentages of Yes and No for each field and for each evaluator are shown in Table 7.

Table 7. Results of empirical observation grid expressed in percentage.

\begin{tabular}{lccccccccc}
\hline & \multicolumn{3}{c}{ Motivation } & \multicolumn{2}{c}{ Understanding } & \multicolumn{2}{c}{ Collaboration } \\
\cline { 2 - 10 } & Day 1 & Day 2 & Day 3 & Day 1 & Day 2 & Day 3 & Day 1 & Day 2 & Day 3 \\
\hline \multirow{2}{*}{ Observer 1 } & Yes 75\% & Yes 75\% & Yes 75\% & Yes 75\% & Yes 81\% & Yes 75\% & Yes 81\% & Yes 88\% & Yes 81\% \\
& No 25\% & No 25\% & No 25\% & No 25\% & No 19\% & No 25\% & No 19\% & No 12\% & No 19\% \\
Observer 2 & Yes 75\% & Yes 81\% & Yes 69\% & Yes 81\% & Yes 88\% & Yes 75\% & Yes 88\% & Yes 88\% & Yes 81\% \\
& No 25\% & No 19\% & No 31\% & No 19\% & No 12\% & No 25\% & No 12\% & No 12\% & No 19\% \\
Observer 3 3 & Yes 75\% & Yes 75\% & Yes 81\% & Yes 81\% & Yes 75\% & Yes 75\% & Yes 94\% & Yes 88\% & Yes 88\% \\
& No 25\% & No 25\% & No 19\% & No 19\% & No 25\% & No 25\% & No 6\% & No 12\% & No 12\% \\
Days Mean & & Yes 76\% & & & Yes 78\% & & & Yes 86\% & No 14\% \\
& & No 24\% & & & No 22\% & & & No $\%$ \\
\hline
\end{tabular}


The most common answers recorded from the interviews are represented in Figure A1, within Appendix A. Responses regarding the perception of PE lessons highlight that free play and competitions were the preferred activities by the CG (44\%). In contrast, EG preferred to learn new exercises and to acquire new knowledge (35\%) that in CG is based on sport skills (31\%); moreover, learning how and why to use a perception scale $(12 \%)$ and consciousness $(12 \%)$ are mentioned only by the EG. Technology and experimentation are reported by EG $(15 \%)$ and CG $(19 \%)$. In the same way, the teachers were appreciated for professional skills jointly with the feedback of students in EG (26\%) and for their passion in CG (6\%). The CG reported dissatisfaction for not being part of EG (53\%) and for missing some activities as volleyball, the yo-yo test and other activities (16\%). The EG reported dissatisfaction in reconciling the gym training with others school commitments (33\%); moreover, the EG reported excessive effort (23\%) and lack of playful aspects (11\%). However, $33 \%$ of the EG and $31 \%$ of CG reported no dissatisfaction with the physical education program content.

\section{Discussion}

\subsection{Functional-Quantitative Approach, Product Referred}

The present study aimed to compare the effect of a specific training program with an ordinary school program carried out in a very peculiar educative environment such as a military school. The main findings showed that varying ordinary physical education with a specific strength plan and circuit training performed twice a week for eight weeks did not improve strength and power capacities, endurance, circuit trainings outcomes and scores achieved following a military test battery in the experimental group compared to a control one. Nevertheless, the experimental group were able to maintain the total score results during the academic year. On the contrary, the total score result of the control group decreased (see Table 5, CG post vs. EG post).

In order to contextualize the physical level of the military school sample, test results have been compared with the literature. Concerning lower limbs, male high school handball players showed similar values of force $(1759 \pm 293 \mathrm{~N})$ and jump height $(42 \pm 4 \mathrm{~cm})$ but lower values of power $(2006 \pm 440 \mathrm{~W})$ in the CMJ test [32]. In power of upper limbs, military students' sample of the present research seemed to have lower power than their American peers in the same exercise $(366.3 \pm 115.7 \mathrm{~W})[33]$.

In the literature, it is well known that circuit training can be useful for improving abilities and health of high school students [34,35]. A recent study found that the circuit training method improved physical fitness parameters as cardiorespiratory fitness, flexibility, jumping ability and isometric arm strength, reducing body fat in adolescents [35]. Another study investigated the effect of circuit training method in high school female sprinters [34]. The circuit training was able to improve sprinting ability, particularly in beginners [34].

In the present research, despite greater values in Session-RPE compared with the control group, the experimental group did not show higher improvements in the different tests and measures compared to the control group. It is worth noting that only one lesson per week was dedicated to strength and power training and only one lesson of the same length was dedicated to circuit training. Some authors have investigated the effects of different strength and power session on squat jump and bench press throw in men [36]. These studies evaluated peak power and peak force in squat jump [36], and the maximal velocity and the load at maximal repetition [37]. These studies showed that three training sessions per week for fourteen weeks were able to improve strength and power. A similar training volume of circuit training has been shown to improve lower limb strength and power in non-athlete male individuals [38]. However, it should be noted that these protocols could not be adopted in the scholastic system due to reduced school hours.

In the literature it is evidenced that athlete-students can experience greater amounts of stress due to physical and scholastic demand [39]. This is accompanied by an increment in cortisol level that, when excessive, might negatively influence physical performance and impair recovery [40]. Although 
stress is indispensable in promoting physical improvement [41], excessive levels of physical stress can reduce the body's adaptation capacity [42]. Comparing students of Military School and Scientific High School, it is evident how MS students seem to have higher values of variables considered to be stress-related (MD, PD, TD, and E). This was probably caused by a higher load in the academic program, military career admission tests simulations, exercises and military routine. Moreover, the higher values of Session-RPE reported by the experimental group in most sessions enhances the idea of a negative effect due to excessive physical and scholastic load.

\subsection{Phenomenological-Qualitative Approach, Process Referred}

The methodological approach has made extensive use of a reflective approach and cooperative learning [43], providing an abundance of student-centered activities in which it also gave a certain autonomy to the students by putting them at the center of the learning experience [44]. This emerged very well in the data collected with the observation grid and in the answers of the 16 students to the questions asked at the end of the project. As seen in other studies that have investigated the effect of cooperative learning, by evaluating the results, positive effects emerged on the classroom climate and on learning, favored by the relationship and by the direct and conscious involvement of students in the research-action work $[45,46]$. Of note, students increased their awareness of the presence of a relationship between specific motor areas and other areas, such as the cognitive and psychological ones, involved in the daily routine of college military life and in other school commitments (Table 4). Again, from the interviews it is possible to observe that the students also better understood the activities to be carried out thanks to the teacher's support and the tools used, such as perceptive scales and technological instrumentation. This active involvement stimulated interest and motivation during the intervention. In particular, autonomy, competences, and social-relation capacity are fundamental elements of scholastic didactics and play a crucial role in both physical and cognitive development and quality of life. It should be acknowledged that in the present study we assessed the quantity of motivation (using observation indicators) rather than the quality of motivation, which can be either intrinsic or extrinsic [47]. We provide evidence that further studies should consider the assessment of the quality of motivation, as it has been shown that intrinsic motivation is related to adolescents' performance in moderate-to-vigorous physical activity [48].

\section{Conclusions}

It is possible to conclude that an intervention based on circuit training, power training and strength training did not improve physical performance in military high school students when included into a scholastic reality at the military high school. In this environment, the limited amount of physical education hours (due to ministerial programs) and the high psychophysical effort probably interfered with the expected improvement. Nevertheless, the application of a method based on an action-reflection principle, where participants are protagonists of their improvement and learning process, was widely appreciated by the students, demonstrating the sustainability of our educational approach. This highlights how an active involvement can interact with interest and motivation during the intervention, differently from an aseptic results-based approach. Moreover, it is worth noting the importance of active reflection during physical education class as a multidisciplinary learning tool.

Author Contributions: Conceptualization, P.L.I., A.B.; data curation, G.S., M.P. and A.B.; formal analysis, G.S. and A.B.; investigation, G.S., P.L.I. and A.B.; methodology, P.L.I. and A.B.; supervision, P.L.I., G.A. and D.F.; visualization, P.L.I, G.A. and D.F.; writing-original draft preparation, P.L.I., G.S., A.B. and D.F.; writing一review and editing, P.L.I., G.S., M.P., G.A., D.F. and A.B. All authors have read and agreed to the published version of the manuscript.

Funding: This research received no external funding.

Conflicts of Interest: The authors declare no conflict of interest. 


\section{Appendix A}

What did you like about the lessons? Why?

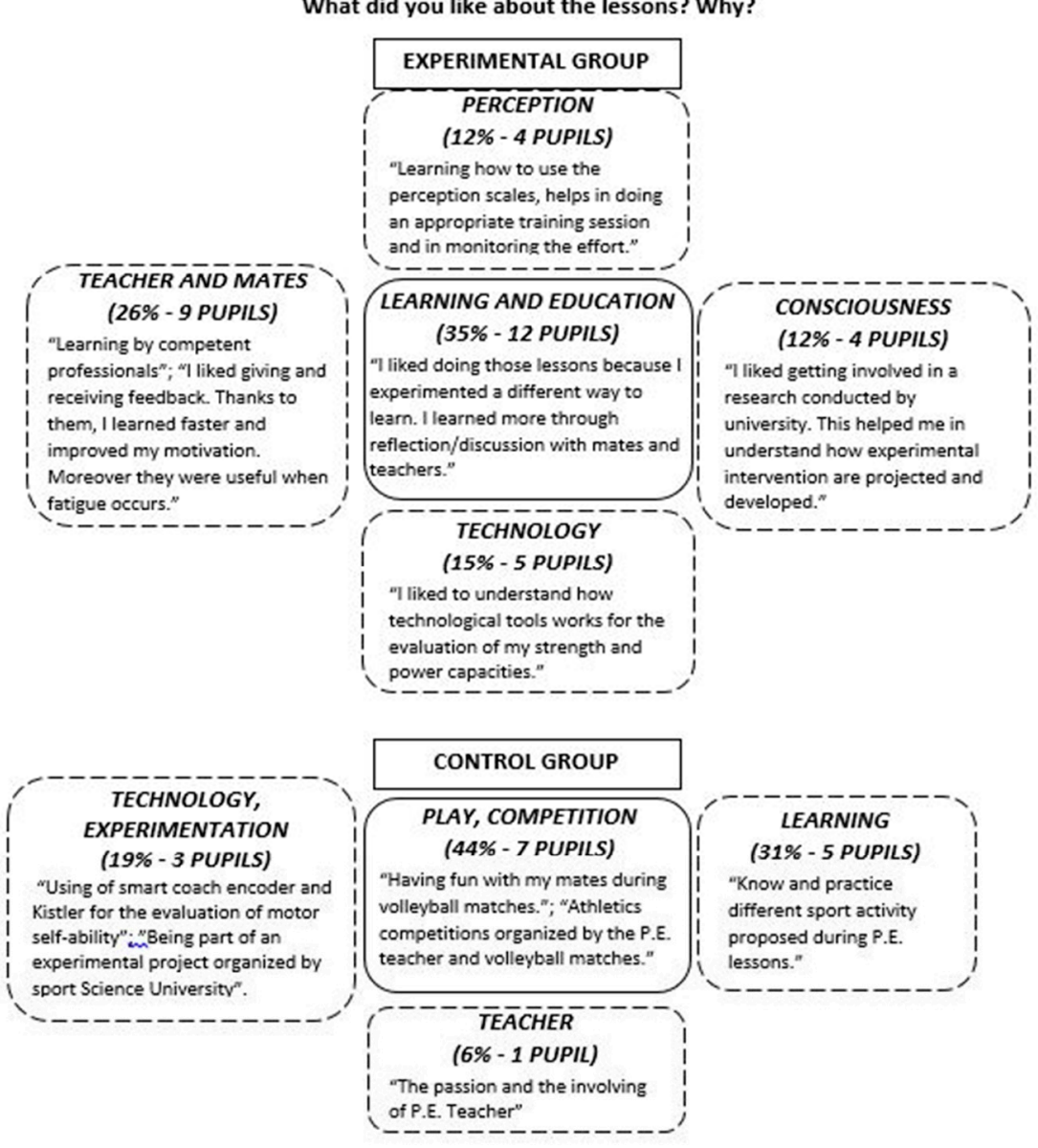

What didn't you like? Why?

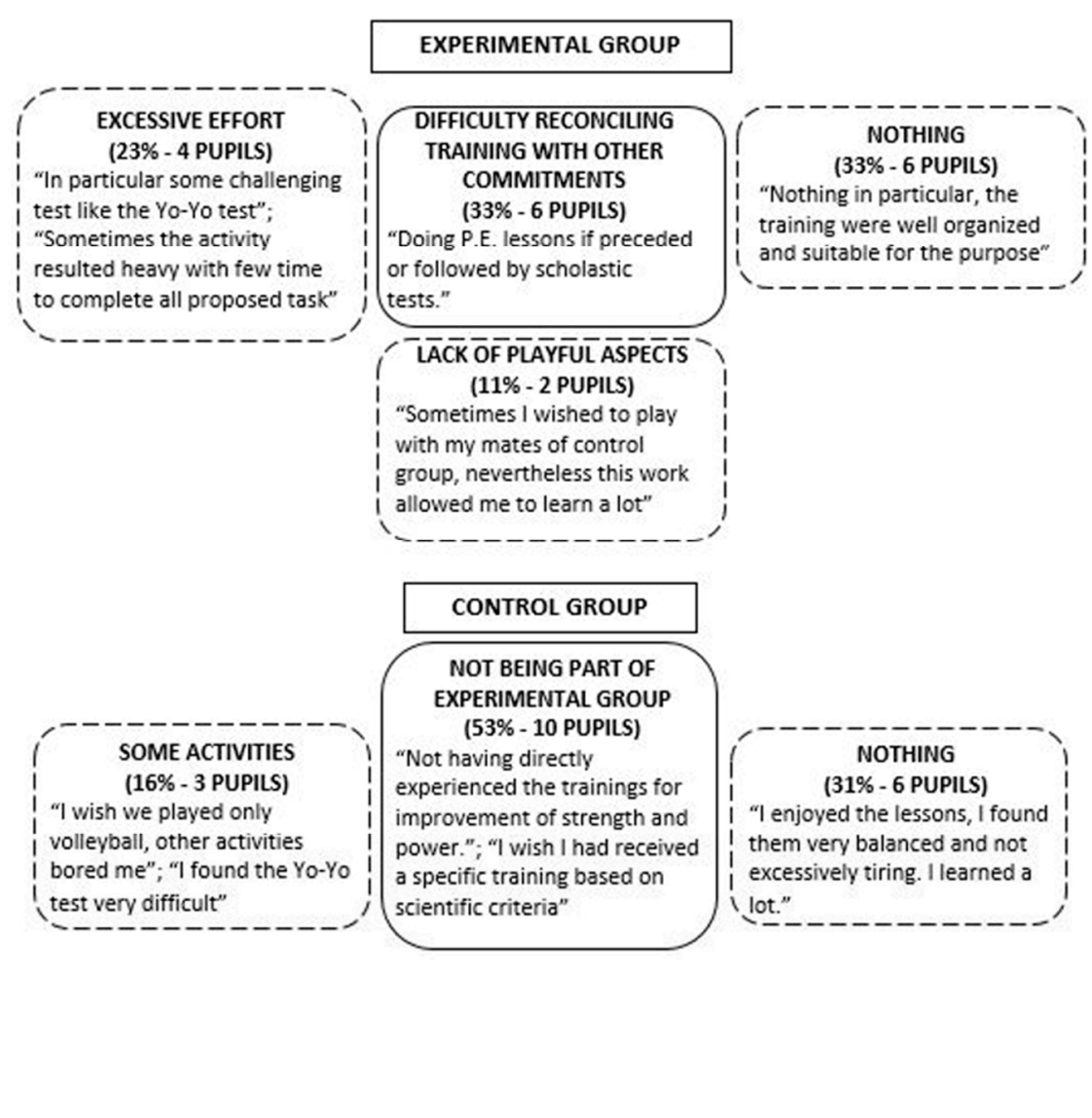

Figure A1. Schematic representation of answers detected from the interview of the control and experimental groups with percentages of responses. 


\section{References}

1. Heinrich, K.M.; Spencer, V.; Fehl, N.; Carlos Poston, W.S. Mission essential fitness: Comparison of functional circuit training to traditional Army physical training for active duty military. Mil. Med. 2012, 177, 1125-1130. [CrossRef] [PubMed]

2. Roy, T.C.; Springer, B.A.; McNulty, V.; Butler, N.L. Physical fitness. Mil. Med. 2010, 175, 14-20. [CrossRef]

3. Moreno, M.R.; Dulla, J.M.; Dawes, J.J.; Orr, R.R.M.; Cesario, K.; Lockie, R.G. Lower-body power and its relationship with body drag velocity in law enforcement recruits. Int. J. Exerc. Sci. 2019, 12, 847-858.

4. Hunt, W.A.; Wittson, C.L.; Harris, H.I. The screen test in military selection. Psychol. Rev. 1944, 51, 37. [CrossRef]

5. Whitehead, M. The concept of physical literacy. Eur. J. Phys. Educ. 2001, 6, 127-138. [CrossRef]

6. Castoldi, M. Progettare Per Competenze; Carocci: Roma, Italy, 2011.

7. Pellerey, M. Le Competenze Individuali e Il Portfolio; Etas: Milano, Italy, 2004.

8. Mariani, L.; Pozzo, G. Stili, strategie e strumenti nell'apprendimento linguistico. In Imparare a imparare. Insegnare a imparare; La Nuova Italia, Collana LEND: Firenze, Italy, 2002.

9. Reason, P.; Rowan, J. Human Inquiry: A Sourcebook of New Paradigm Research; John Wiley \& Sons: Hoboken, NJ, USA, 1981.

10. Glatthorn, A.A. Performance Standards and Authentic Learning; Eye on Education: Larchmont, NY, USA, 1999.

11. Bosquet, L.; Porta-Benache, J.; Blais, J. Validity of a commercial linear encoder to estimate bench press 1 RM from the force-velocity relationship. J. Sports Sci. Med. 2010, 9, 459.

12. Markovic, G.; Dizdar, D.; Jukic, I.; Cardinale, M. Reliability and factorial validity of squat and countermovement jump tests. J. Strength Cond. Res. 2004, 18, 551-555.

13. Castagna, C.; Impellizzeri, F.M.; Rampinini, E.; D’Ottavio, S.; Manzi, V. The Yo-Yo intermittent recovery test in basketball players. J. Sci. Med. Sport 2008, 11, 202-208. [CrossRef]

14. Krustrup, P.; Mohr, M.; Amstrup, T.; Rysgaard, T.; Johansen, J.; Steensberg, A.; Pedersen, P.K.; Bangsbo, J. The yo-yo intermittent recovery test: Physiological response, reliability, and validity. Med. Sci. Sports Exerc. 2003, 35, 697-705. [CrossRef]

15. Haddad, M.; Stylianides, G.; Djaoui, L.; Dellal, A.; Chamari, K. Session-RPE method for training load monitoring: Validity, ecological usefulness, and influencing factors. Front. Neurosci. 2017, 11, 612. [CrossRef]

16. Hoonakker, P.; Carayon, P.; Gurses, A.P.; Brown, R.; Khunlertkit, A.; McGuire, K.; Walker, J.M. Measuring workload of ICU nurses with a questionnaire survey: The NASA Task Load Index (TLX). IIE Trans. Healthc. Syst. Eng. 2011, 1, 131-143. [CrossRef]

17. Foster, C.; Florhaug, J.A.; Franklin, J.; Gottschall, L.; Hrovatin, L.A.; Parker, S.; Doleshal, P.; Dodge, C. A new approach to monitoring exercise training. J. Strength Cond. Res. 2001, 15, 109-115. [PubMed]

18. Impellizzeri, F.M.; Rampinini, E.; Coutts, A.J.; Sassi, A.; Marcora, S.M. Use of RPE-based training load in soccer. Med. Sci. Sports Exerc. 2004, 36, 1042-1047. [CrossRef]

19. Meyer, J. Using qualitative methods in health related action research. BMJ 2000, 320, 178-181. [CrossRef]

20. EUR-lex. Available online: https://eur-lex.europa.eu/legal-content/IT/TXT/?uri=CELEX\%3A32018H0604\% $2801 \% 29$ (accessed on 23 June 2020).

21. www.gazzettaufficiale.it. Available online: https://www.gazzettaufficiale.it/eli/id/2010/12/14/010G0232/sg (accessed on 23 June 2020).

22. Patterson, P.; Faucette, N. Children's attitudes toward physical activity in classes taught by specialist versus nonspecialist PE teachers. J. Teach. Phys. Educ. 1990, 9, 324-331. [CrossRef]

23. Siedentop, D.; Tannehill, D. Developing teaching skills in physical education; Mayfield Pub Co: Mountain View, CA, USA, 1999.

24. Siedentop, D. Aprender a Enseñar La Educación Física; Editorial INDE: Barcelona, Spain, 1998.

25. Bellack, A.; Kliebard, H.; Hyman, R.; Smith, F. The Language of the Classroom; Teachers College. Columbia University Press: New York, NY, USA, 1966.

26. Lincoln, Y.S.; Guba, E.G. Naturalistic Inquiry; SAGE Publications: Thousand Oaks, CA, USA, 1985.

27. Hill, C.E.; Knox, S.; Thompson, B.J.; Williams, E.N.; Hess, S.A.; Ladany, N. Consensual qualitative research: An update. J. Couns. Psychol. 2005, 52, 196. [CrossRef]

28. Corbin, J.; Strauss, A. Basics of Qualitative Research: Techniques and Procedures for Developing Grounded Theory; SAGE Publications: San Jose State University, CA, USA, 2014. 
29. Hopkins, W.G.; Marshall, S.W.; Batterham, A.M.; Hanin, J. Progressive Statistics for Studies in Sports Medicine and Exercise Science. Med. Sci. Sports. Exerc. 2009, 41, 3-13. [CrossRef]

30. Hopkins, W.G. Estimating sample size for magnitude-based inferences. Sportscience. 2006, pp. 63-70. Available online: Sportsci.org/2006/wghss.htm (accessed on 1 June 2020).

31. Dugnani, S.; Invernizzi, P.L. Progettare in Educazione Fisica e Nella Scienze Motorie; Carabà: Pozzo d'Adda, Italy, 2013.

32. Chelly, M.S.; Hermassi, S.; Aouadi, R.; Shephard, R.J. Effects of 8-week in-season plyometric training on upper and lower limb performance of elite adolescent handball players. J. Strength Cond. Res. 2014, 28, 1401-1410. [CrossRef]

33. Andre, M.J.; Fry, A.C.; McLellan, E.; Weiss, L.W.; Moore, C.M. Acute effects of static stretching on bench press power and velocity in adolescent male athletes. Int. J. Sports Sci. Coach. 2014, 9, 1145-1152. [CrossRef]

34. Babu, M.S.; Kumar, P.P. The effect of selected circuit training exercises on sprinters of high school girls. Int. J. Sci. Res. 2013, 2, 401-407.

35. Giannaki, C.D.; Aphamis, G.; Tsouloupas, C.N.; Ioannou, Y.; Hadjicharalambous, M. An eight week school-based intervention with circuit training improves physical fitness and reduces body fat in male adolescents. J. Sports Med. Phys. Fit. 2016, 56, 894-900.

36. Cormie, P.; McGuigan, M.R.; Newton, R.U. Adaptations in athletic performance after ballistic power versus strength training. Med. Sci. Sports Exerc. 2010, 42, 1582-1598. [CrossRef] [PubMed]

37. Hartmann, H.; Bob, A.; Wirth, K.; Schmidtbleicher, D. Effects of different periodization models on rate of force development and power ability of the upper extremity. J. Strength Cond. Res. 2009, 23, 1921-1932. [CrossRef] [PubMed]

38. Chtara, M.; Chaouachi, A.; Levin, G.T.; Chaouachi, M.; Chamari, K.; Amri, M.; Laursen, P.B. Effect of concurrent endurance and circuit resistance training sequence on muscular strength and power development. J. Strength Cond. Res. 2008, 22, 1037-1045. [CrossRef] [PubMed]

39. Hudd, S.S.; Dumlao, J.; Erdmann-Sager, D.; Murray, D.; Phan, E.; Soukas, N.; Yokozuka, N. Stress at college: Effects on health habits, health status and self-esteem. Coll. Stud. J. 2000, 34, 217.

40. Hug, M.; Mullis, P.E.; Vogt, M.; Ventura, N.; Hoppeler, H. Training modalities: Over-reaching and over-training in athletes, including a study of the role of hormones. Best Pract. Res. Clin. Endocrinol. Metab. 2003, 17, 191-209. [CrossRef]

41. Rapolienè, L.; Razbadauskas, A.; Jurgelènas, A. The reduction of distress using therapeutic geothermal water procedures in a randomized controlled clinical trial. Adv. Prev. Med. 2015, 2015, 749417. [CrossRef]

42. Bartholomew, J.B.; Stults-Kolehmainen, M.A.; Elrod, C.C.; Todd, J.S. Strength gains after resistance training: The effect of stressful, negative life events. J. Strength Cond. Res. 2008, 22, 1215-1221. [CrossRef] [PubMed]

43. Slavin, R.E. Cooperative learning and the cooperative school. Educ. Leadersh. 1987, 45, 7-13.

44. Dyson, B. Cooperative learning in an elementary physical education program. J. Teach. Phys. Educ. 2001, 20, 264-281. [CrossRef]

45. Goodwin, M.W. Cooperative learning and social skills: What skills to teach and how to teach them. Interv. Sch. Clin. 1999, 35, 29-33. [CrossRef]

46. Herrmann, K.J. The impact of cooperative learning on student engagement: Results from an intervention. Act. Learn. High. Educ. 2013, 14, 175-187. [CrossRef]

47. Ryan, R.M.; Deci, E.L. Intrinsic and extrinsic motivation from a self-determination theory perspective: Definitions, theory, practices, and future directions. Contemp. Educ. Psychol. 2020, in press. [CrossRef]

48. Kalajas-Tilga, H.; Koka, A.; Hein, V.; Tilga, H.; Raudsepp, L. Motivational processes in physical education and objectively measured physical activity among adolescents. J.Sport Health Sci. 2019. [CrossRef]

(C) 2020 by the authors. Licensee MDPI, Basel, Switzerland. This article is an open access article distributed under the terms and conditions of the Creative Commons Attribution (CC BY) license (http://creativecommons.org/licenses/by/4.0/). 